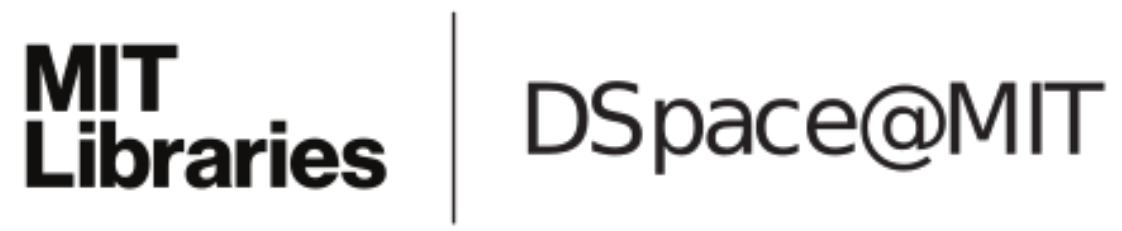

\author{
MIT Open Access Articles
}

Defensins, lectins, mucins, and secretory immunoglobulin A: microbe-binding biomolecules that contribute to mucosal immunity in the human gut

The MIT Faculty has made this article openly available. Please share how this access benefits you. Your story matters.

Citation: Chairatana, Phoom, and Nolan, Elizabeth M. . "Defensins, Lectins, Mucins, and Secretory Immunoglobulin A: Microbe-Binding Biomolecules That Contribute to Mucosal Immunity in the Human Gut." Critical Reviews in Biochemistry and Molecular Biology 52, 1 (November 2016): 45-56 (c) 2016 Informa UK Limited, trading as Taylor \& Francis Group. Keywords: Mucosal immunity; Paneth cells; host defense; defensins; lectins; mucins; slgA

As Published: http://dx.doi.org/10.1080/10409238.2016.1243654

Publisher: Informa UK Limited

Persistent URL: http://hdl.handle.net/1721.1/113394

Version: Author's final manuscript: final author's manuscript post peer review, without publisher's formatting or copy editing

Terms of use: Creative Commons Attribution-Noncommercial-Share Alike 


\title{
Defensins, Lectins, Mucins and Secretory Immunoglobulin A: Microbe-Binding Biomolecules that Contribute to Mucosal Immunity in the Human Gut
}

\author{
Phoom Chairatana ${ }^{1}$ and Elizabeth M. Nolan ${ }^{1, *}$ \\ ${ }^{1}$ Department of Chemistry, Massachusetts Institute of Technology, Cambridge, MA 02139, USA
}

\begin{abstract}
In the intestine, the mucosal immune system plays essential roles in maintaining homeostasis between the host and microorganisms, and protecting the host from pathogenic invaders. Epithelial cells produce and release a variety of biomolecules into the mucosa and lumen that contribute to immunity. In this review, we focus on a subset of these remarkable host-defense factors - enteric a-defensins, select lectins, mucins, and secretory immunoglobulin A - that have the capacity to bind microbes and thereby contribute to barrier function in the human gut. We provide an overview of the intestinal epithelium, describe specialized secretory cells named Paneth cells, and summarize our current understanding of the biophysical and functional properties of these select microbe-binding biomolecules. We intend for this compilation to complement prior reviews on intestinal host-defense factors, highlight recent advances in the field, and motivate investigations that further illuminate molecular mechanisms as well as the interplay between these molecules and microbes.
\end{abstract}

\section{Keywords}

mucosal immunity; Paneth cells; host defense; defensins; lectins; mucins; $\operatorname{sg} \mathrm{A}$

\section{Introduction to Intestinal Mucosal Immunity}

The immune system protects the host from microbial infections (Parkin and Cohen, 2001). This system can be divided into innate and adaptive immunity (Parkin and Cohen, 2001). Both systems distinguish between self and nonself, albeit by different mechanisms. The innate immune system relies on certain receptors and secreted proteins that recognize common features (e.g. lipopolysaccharide) among various pathogens (Dommett et al., 2005). In contrast, the adaptive immune system employs a process of somatic cell gene rearrangement to generate a vast repertoire of antigen receptors that discriminate closely related molecules (Litman et al., 2010). Although adaptive immune responses are more specific to pathogenic invaders than innate immune responses, the adaptive immune system takes longer to respond to pathogens (Dommett et al., 2005, Litman et al., 2010). As a result, the innate immune system provides a first line of host defense to counteract pathogenic

*Corresponding author: lnolan@mit.edu, Phone: 617-452-2495, Fax: 617-324-0505. 
invasion at the mucosa (Dommett et al., 2005, Santaolalla et al., 2011, Peterson and Artis, 2014). In this review, we consider a subset of host-defense molecules that contribute to immunity at the intestinal mucosa by interacting with microbes and contributing to barrier function as described below.

The intestinal epithelium is a key contributor to intestinal innate immunity (Figure 1). It creates physical and chemical barriers that protect the host (Peterson and Artis, 2014). The intestinal epithelium (Figure 1) is composed of four cell lineages, namely enterocytes, enteroendocrine cells, goblet cells, and Paneth cells, all of which are derived from a common stem cell progenitor in the intestinal crypts (Cheng, 1974a, Cheng, 1974b, Cheng and Leblond, 1974a, Cheng and Leblond, 1974b). Moreover, the intestinal epithelial cells are held together by tight junctions, which effectively form a seal against the external milieu. The majority of epithelial cells bordering the intestinal lumen are absorptive enterocytes, which are important for metabolic and digestive function (Snoeck et al., 2005). Secretory intestinal epithelial cells, which include enteroendocrine cells, goblet cells, and Paneth cells ( vide infra), contribute to the barrier function of the epithelium (Furness et al., 2013). Enteroendocrine cells provide communication between the central and enteric neuroendocrine systems via the secretion of several hormones that regulate digestive function (Furness et al., 2013). Goblet cells (Specian and Oliver, 1991) and Paneth cells (Clevers and Bevins, 2013) secrete mucus and antimicrobial peptides (AMPs), respectively, to promote the removal of microbes from the mucosal surface. The transcytosis and luminal release of secretory immunoglobulin A ( $\operatorname{IgA}$ ) by plasma cells further enforce this barrier function (Mantis et al., 2011). Moreover, beneath the epithelium is the lumina propria, where macrophages and dendritic cells (DCs) reside (Cerovic et al., 2014). Macrophages function as innate effector cells by engulfing and removing invading microbes, secreting cytokines, and maintaining intestinal homeostasis. In contrast, DCs migrate from the intestine to the mesenteric lymph nodes (MLNs) and initiate adaptive immune responses by priming naïve $\mathrm{T}$ cells.

The importance of intestinal mucosal immunity is highlighted by the fact that the intestinal lumen is topologically outside of the body. As a result, the intestinal epithelium is constantly exposed to foreign materials that are ingested, including pathogenic microorganisms (Santaolalla et al., 2011). Moreover, trillions of commensal microbes, also known as the microbiota, reside in the intestinal tract. The commensals contribute to intestinal health because these organisms compete with pathogens for nutrients and for attachment sites on epithelial cells, preventing invading pathogens from colonizing (Costello et al., 2009, Qin et al., 2010). This phenomenon is termed colonization resistance and is beneficial to the host. Nevertheless, commensal microbes can cause disease under certain circumstances (e.g., overgrowth, immunocompromised hosts) (Hooper et al., 2012). Thus, to prevent overgrowth of the commensal population as well as prohibit pathogens from colonizing and causing infections, the host must maintain tight control over intestinal homeostasis.

In summary, mucosal immunity in the intestine involves a complex network of different types of cells that work together to provide physical and chemical barriers against microbial invasion, and maintain homeostasis. Indeed, defects in the innate immune system can result in increased susceptibility to Crohn's disease and microbial infections, even in the presence 
of a functional adaptive immune system (Wehkamp and Stange, 2010). Against this backdrop, we consider the chemistry and biology of several immune factors that are released into the intestinal lumen and contribute to barrier function in the following sections. We begin with a discussion of intestinal Paneth cells because these secretory cells release two classes of microbe-binding molecules that we discuss below, enteric a-defensins and lectins.

\section{Paneth Cells}

Paneth cells are granule-rich epithelial cells that are located at the base of crypts of Lieberkühn in the small intestine (Figure 1). These secretory cells are found in humans, marsupials, mice and rats, whereas some mammals (e.g. cows and sheep) lack them (Porter et al., 2002). Paneth cells store variety of peptides and proteins in secretory granules. Hostdefense biomolecules, including a-defensins (cryptdins in mice; of note, the murine defensin repertoire differs from that of the human peptides) (Porter et al., 1997a, Ouellette et al., 1999), lysozyme C (Ghoos and Vantrappen, 1971), phospholipases (Kiyohara et al., 1992), and the C-type lectin REG3a (REG3 $\gamma$ in mice) (Lasserre et al., 1999) are the most abundant constituents of the granules. Paneth cell degranulation occurs in response to stimuli that include cholinergic agonists (Satoh et al., 1995), bacteria, and bacterial products such as lipopolysaccharide (LPS) and lipoteichoic acid (Ayabe et al., 2000). Degranulation results in the release of these host-defense molecules into the mucus layer and lumen. By disseminating into the mucus layer, these biomolecules contribute to the mucosal barrier and prevent microbial invasion of the crypt (Peterson and Artis, 2014). Because the small intestine is constantly exposed to bacteria and bacterial products, it is reasoned that Paneth cells continuously secrete antimicrobials at baseline levels, and that higher amounts are released upon stronger stimulation (Ayabe et al., 2000). The contributions of Paneth cells to innate immunity are comprehensively discussed in several other reviews (Bevins and Salzman, 2011, Clevers and Bevins, 2013).

\section{Defensins}

Defensins are small ( $<50$ amino acids), cationic, cysteine-rich host-defense peptides produced by lower and higher eukaryotes (Evans et al., 1994, Harwig et al., 1994, Broekaert et al., 1995, Destoumieux et al., 1997, Lehrer and Ganz, 1999, Zou et al., 2007, Zhu, 2008). Defensins are ribosomally synthesized and the mature peptides exhibit regiospecific disulfide linkages in the oxidized forms. The vertebrate defensins contain three disulfide bonds and are categorized into three subfamilies, $a-, \beta-$, and $\theta$-defensins, based on the regiospecific disulfide-bond linkages (Figure 2) (Ganz, 2003). Both $\alpha$ - and $\beta$-defensins are produced by humans and consist of a triple-stranded $\beta$-sheet fold with six cysteine residues

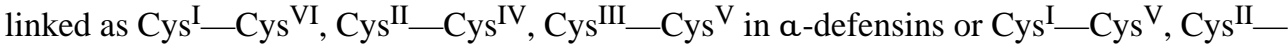
$\mathrm{Cys}^{\mathrm{IV}}$, Cys ${ }^{\mathrm{III}}-\mathrm{Cys}{ }^{\mathrm{VI}}$ in $\beta$-defensins (the numbering indicates the Cys ordering from $\mathrm{N}$ to $\mathrm{C}$ terminus). $\theta$-Defensins have only been isolated from non-human primates and are structurally distinct from $a$ - and $\beta$-defensins. The backbone of the $\theta$-defensins is a cyclic peptide that is formed via splicing and cyclization from two of the nine-residue segments of a-defensin-like precursor peptides (Tang et al., 1999). The six cysteine residues in $\theta$ defensins are linked as a cyclic cysteine ladder motif (Conibear et al., 2012). 
The expression and localization of each class of defensins vary from organism to organism.

Six $\alpha$-defensins and four $\beta$-defensins have been detected in human specimens and characterized, and additional human $\beta$-defensin genes have been identified (Linzmeier et al., 1999). For the purposes of this review, we focus on two peptides, the human enteric adefensins 5 and 6 (HD5 and HD6), that contribute to innate immunity in the gut. Both HD5 and HD6 are expressed in duodenum, jejunum, and ileum of the small intestine; the highest expression levels are observed in the ileum (Jones and Bevins, 1992). Both peptides are constitutively expressed and co-packaged in the granules of small intestinal Paneth cells (Jones and Bevins, 1992, Chairatana et al., 2016), and released into the intestinal lumen following degranulation. For information on other human defensins, we refer the reader to several recent reviews that provide comprehensive overviews of these host-defense peptides (Lehrer and Lu, 2012, Zhao and Lu, 2014).

\section{Human a-Defensin 5 (HD5) Is Antimicrobial and Exhibits Lectin-like Properties}

HD5 is the most abundant host-defense peptide produced by small intestinal Paneth cells (Porter et al., 1997a). Indeed, the transcriptional levels of HD5 are reported to be 4-6-fold greater than that of HD6, and higher than other antimicrobial substances in the Paneth cell granules (Wehkamp et al., 2006). HD5 was first detected in the human small intestine (Jones and Bevins, 1992), and subsequent investigations revealed that the peptide is also produced in the female reproductive tract (Quayle et al., 1998), the pancreas (Wehkamp et al., 2006), and the kidney and urinary tract (Spencer et al., 2012).

HD5 is biosynthesized as a 94-residue prepropeptide (Figure 3) that consists of an Nterminal 19-residue signal peptide that directs the peptide to the secretory pathway, a 43residue pro region, and a 32-residue $\mathrm{C}$-terminal region that corresponds to the mature peptide (Jones and Bevins, 1992). The cationic mature peptide has an overall charge of +4 at neutral $\mathrm{pH}$. The disulfide-linked form is amphipathic with the cationic arginine residues positioned on one side of the monomer and most hydrophobic residues positioned on the other side of the monomer (Figure 4). Following cleavage of the 19-residue signal sequence, HD5 is stored in Paneth cell granules as the 75-residue propeptide (proHD5) (Cunliffe et al., 2001, Ghosh et al., 2002). Proteolytic processing of proHD5 affords mature HD5 either during or after degranulation. Trypsin is housed in the Paneth cell granules, and it has been identified as the protease that cleaves proHD5 to afford mature HD5 (Ghosh et al., 2002). The mature peptide contains six arginine residues, and the disulfide-linked form exhibits protease resistance (Wanniarachchi et al., 2011).

HD5 is recognized as an antimicrobial peptide that can kill a broad range of microbes, at least under laboratory conditions (Porter et al., 1997b, Ericksen et al., 2005, Wommack et al., 2014, Furci et al., 2015). Seminal investigations that employed a HD5 transgenic mouse revealed that HD5 expression in the small intestine confers resistance to oral Salmonella enterica serovar Typhimurium challenge (Salzman et al., 2003). Subsequent studies of these mice supported a homeostatic role of HD5 in modulating the composition of the intestinal 
microbiota (Salzman et al., 2010). Taken together, these observations indicate that HD5 is important for both defense against pathogens and maintaining intestinal homeostasis.

Although the antimicrobial properties of HD5 are most well known, this peptide has other noteworthy characteristics. We note here that HD5 displays lectin-like behavior. It binds to glycosylated proteins (Lehrer et al., 2009), LPS (Thomassin et al., 2013, Moser et al., 2014), and bacterial toxins (Wei et al., 2009, Kudryashova et al., 2014). Interaction of HD5 with the bacterial toxin $\mathrm{ACD}_{V_{c}}$ induced toxin unfolding and enhanced the susceptibility of the toxin to proteolysis. This work, along with studies of the human neutrophil a-defensin HNP1, provided the basis for a new model for defensin host-defense function whereby unfoldase activity results in stabilization of non-native states of bacterial toxins, resulting in aggregation or proteolysis (Wei et al., 2009, Kudryashova et al., 2014). Additional evidence for lectin-like behavior comes from microscopy studies of Escherichia coli exposed to HD5, which revealed that the peptide causes the bacteria cells to clump together (Chileveru et al., 2015). Thus, although HD5 has broad-spectrum antimicrobial activity, these studies indicate that HD5 function is multi-faceted and that the peptide has the capacity to affect microbes in ways other than cell killing.

\section{Human a-Defensin 6 (HD6) Entraps Microbes and Blocks Host Cell Invasion}

HD6 is produced by Paneth cells of the small intestine and stored in the granules (Jones and Bevins, 1993). Similar to HD5, HD6 is biosynthesized as a prepropeptide. The 100-aa prepropeptide contains an $\mathrm{N}$-terminal 19-residue signal sequence that directs the peptide to the secretory pathway, a 49-residue pro region, and a 32-residue C-terminal region that corresponds to the mature peptide. HD6 is stored in the granules of Paneth cells as a propeptide (proHD6) and, similar to HD5 maturation, trypsin has been identified as the processing enzyme that cleaves the pro domain to release mature HD6 in the intestinal lumen (Chairatana et al., 2016). The mature peptide has an overall charge of +2 at neutral pH (Jones and Bevins, 1993). Similar to HD5, the disulfide bonds in HD6 confer protease resistance (Chairatana et al., 2016).

The contribution of HD6 to mucosal immunity was enigmatic for many years. Although the tertiary structure of the HD6 monomer looks similar to those of HD5 and other a-defensins (Figure 4 and 5), HD6 differs from these peptides because it exhibits negligible antimicrobial activity (Ericksen et al., 2005, Szyk et al., 2006, Chu et al., 2012). In 2012, a new and unprecedented model for HD6 was presented: rather than killing microbes, HD6 self-assembles into higher-order oligomers (Figure 6a) that are named "nanonets" to entrap pathogens and prevent them from invading into host cells (Chu et al., 2012). This study demonstrated that transgenic mice expressing HD6 exhibit resistance to oral $S$.

Typhimurium challenge; however, the Salmonella burden in the feces of these transgenic mice remains high (Chu et al., 2012), indicating that the observed protective effect does not result from antibacterial activity against this pathogen. Microscopic examination of the intestinal lumen of wild-type mice and HD6-transgenic mice challenged with $S$.

Typhimurium revealed that the Salmonella were entrapped in a web-like material in the intestine of the HD6-transgenic mice, but not in the wild-type mice. In further support for the notion that HD6 entraps bacterial pathogens, HD6 blocks the ability of $S$. Typhimurium 
(Chu et al., 2012) and Listeria monocytogenes (Chairatana and Nolan, 2014) to invade cultured epithelial cells. Lastly, scanning electron microscopy of $S$. Typhimurium cultures treated with HD6 revealed cellular clumping and web-like structures that are the HD6 "nanonets" (Chu et al., 2012).

The HD6 "nanonets" indicate that this peptide exhibits markedly different self-association properties than other defensins, the latter of which form lower-order oligomers (Hill et al., 1991, Szyk et al., 2006, Pazgier et al., 2012, Rajabi et al., 2012, Wommack et al., 2012,

Zhao et al., 2012). Two structure/activity relationship studies probed the molecular basis for HD6 self-assembly (Chu et al., 2012, Chairatana and Nolan, 2014). A H27W variant of HD6 was first shown to have defective self-assembly properties, which resulted in loss of functional activity (Chu et al., 2012). As a result, it was proposed that electrostatic interactions between the imidazole rings of His27 and the C-terminal carboxyl groups of Leu32 mediate higher-order oligomerization of HD6 (Chu et al., 2012). Nevertheless, subsequent studies demonstrated that the H27A variant retained the ability to form higherorder oligomers (albeit with different morphology than the native peptide) and block microbial invasion into epithelial cells (Chairatana and Nolan, 2014). An alternative hypothesis based on a comparison of the primary sequences of the six human a-defensins and a crystal structure of HD6 (Figure 6b) (Szyk et al., 2006) was therefore proposed where formation of a hydrophobic pocket between four HD6 monomers drives self-assembly (Chairatana and Nolan, 2014). Two phenylalanine residues, Phe2 and Phe29, are poised in this pocket. Indeed, mutation of either hydrophobic residue to Ala affords HD6 variants that only form monomers and dimers under conditions where HD6 forms large self-assemblies that resemble fibrils, and these variants lack biological function (Chairatana and Nolan, 2014). Moreover, the N-terminal proregion of proHD6 blocks self-assembly and functional activity (Chairatana et al., 2016). This observation affords a model where proHD6 is packaged in the Paneth cell granules as an inactive form, and trypsin-catalyzed cleavage of the propeptide to release mature HD6 triggers self-assembly and functional activity (Chairatana et al., 2016). Nonetheless, precisely how the pro sequence suppresses the selfassembly biological function of HD6 remains unclear. Given that the N-terminal residues of the mature peptide contribute to the hydrophobic pocket observed in the HD6 crystal structure (Figure 6b), it is likely that the N-terminal extension disrupts HD6 oligomerization; however, whether the proregion is disordered or interacts with the C-terminal region is unknown. Similar questions about how the pro sequences modulate the biophysical and functional properties of other defensins also exist, warranting further investigations. Lastly, the structure/activity relationship studies on HD6 further exemplify that variations in the primary sequences of defensins lead to different biophysical properties and biological functions of these peptides (Wannarachchi et al., 2011, Chairatana and Nolan, 2014). Further structural and biophysical studies, including analyses of the fibrils under different experimental conditions, are required to understand the HD6 self-assembly process and contributions of individual amino acid side-chains at the molecular level.

\section{C-type Lectins}

Lectins are carbohydrate-binding proteins that contribute to mucosal innate immunity. Human REG3a (also known as hepatocarcinoma intestine-pancreas/pancreatic associated 
proteins, HIP/PAP) and its murine homolog REG3 $\gamma$ are C-type soluble lectins found throughout the small intestinal epithelium (Christa et al., 1996, Lasserre et al., 1999). CType lectins are calcium-dependent. REG3 lectins are produced by Paneth cells and secreted into the lumen, where they interact with intestinal microbes (Choi et al., 2013).

Several recent studies provide a model for the host-defense function of REG3a (Lehotzky et al., 2010, Loonen et al., 2014, Mukherjee et al., 2014). The interactions between REG3a and its bacterial targets are initiated when REG3a binds to the peptidoglycan of the bacterial cell wall (Lehotzky et al., 2010, Loonen et al., 2014). REG3a recognition of peptidoglycan involves binding to the extended carbohydrate chains on the bacterial surfaces, but not to shorter, soluble peptidoglycan chains that are shed by bacteria. This selectivity for extended carbohydrate chains allows REG3a to interact with the bacterial surface and not be sequestered by shed glycans (Lehotzky et al., 2010). Recent studies indicate that, after binding to the peptidoglycan, REG3a can permeabilize the bacterial membrane by utilizing its cationic residues to interact with the negatively charged bacterial membrane (Mukherjee et al., 2014). Moreover, upon contact with lipids, REG3a can oligomerize to form hexameric transmembrane pores (Mukherjee et al., 2014). On the basis of these observations, both bacterial binding and membrane permeabilization are proposed to be important for the bactericidal activity of REG3a. Lastly, REG3a exhibits antibacterial activity against Gram-positive bacteria because the peptidoglycan is accessible on the outer surfaces of these organisms (Cash et al., 2006). In contrast, the peptidoglycan in Gramnegative bacteria is shielded by the outer membrane and is therefore inaccessible to REG3a.

\section{Intelectins}

Intelectins (IntLs) are classified as X-type lectins, and these biomolecules have been identified in chordates. The $\mathrm{X}$-type lectins are reported to exhibit calcium-dependent function; however, these lectins do not contain the calcium-dependent sequence motif that is conserved in C-type lectins (Weis et al., 1998). Instead, IntLs contain a fibrinogen-like domain (FBD) and are proposed to function similarly to ficolins, a class of FBD-containing lectins that contribute to innate immunity (Thomsen et al., 2011). In mammals, IntLs are predominantly produced by lung cells, intestinal goblet cells, and intestinal Paneth cells (Tsuji et al., 2001, Voehringer et al., 2007).

Human IntL-1 (hIntL-1) is a secretory glycoprotein consisting of polypeptides and $N$-linked oligosaccharides. It binds galactofuranose, a sugar found only in microorganisms, and hence may serve as a microbial pattern element (Tsuji et al., 2001). Recent studies demonstrated that hIntL-1 selectively binds glycans with terminal 1,2-diol groups (Wesener et al., 2015), providing new molecular-level insight into how it recognizes binding partners. In total, hIntL-1 exemplifies how lectins can distinguish microbes from mammalian cells in the innate immune response.

\section{Mucins}

Mucins are the main structural components of mucus, which is a biopolymer found throughout the gastrointestinal tract. This organ system exhibits the highest expression levels 
and diversity of mucins in the body (Linden et al., 2008). Moreover, mucus plays a multifaceted role in the interactions between microbes and the epithelium (Linden et al., 2008). Mucins are high-molecular-weight glycoproteins containing a tandem repeat region (TRR, Figure 7) that is rich in proline, threonine, and serine residues (called PTS sequences). The serine and threonine residues in the TRR are heavily glycosylated with $O$-linked ( $O$-glycans) and less common $N$-linked ( $N$-glycans) oligosaccharides, which results in large, flexible, rod-like molecules of mucins with viscoelastic properties (Bergstrom and Xia, 2013). More than 20 genes encoding mucins have been identified in humans (Corfield, 2015).

Mucins can be categorized into two main groups (Figure 7), namely membrane-bound and secreted proteins (Corfield, 2015). Membrane-bound mucins, including MUC1, MUC3A/B, MUC4, MUC11-13, MUC15-17, MUC20, and MUC21, are essential components of the glycocalyx of mucosal surfaces and play important roles in cell-cell and cell-matrix interactions as well as in cell signaling (Jonckheere and Van Seuningen, 2010). These mucins may be shed from the surface and subsequently integrate into the overlying mucus layer (Hattrup and Gendler, 2008). Secreted mucins are further divided into two subfamilies, namely gel-forming (MUC2, MUC5AC, MUC5B, MUC6, and MUC19) and non-gelforming (MUC7) mucins (Kaur et al., 2013). Secreted mucins are the core structural components of the mucus gel. In the gastrointestinal tract, mucins are produced and secreted by the goblet cells of the small intestine and colon, and the surface mucus cells of the stomach (Kim and Khan, 2013). The oligomerized mucins form homo-oligomers via intermolecular disulfide bonds that create linkages between the cysteine-rich $\mathrm{D}$ domains found in the $\mathrm{N}$ - and C-termini of these mucins (Thornton et al., 2008). Mucin assembly is complex and many steps take place in the secretory pathway. $N$-Glycosylation and Cterminal dimerization occur in the endoplasmic reticulum, followed by $O$-glycosylation in the Golgi, and mucins are packaged into granules prior to secretion (Thornton et al., 2008).

In the small intestine, mucin 2 (MUC2) is the major component of mucus (McGuckin et al., 2011). Within the endoplasmic reticulum (ER), newly synthesized MUC2 peptides dimerize via the formation of disulfide bonds and the dimers are transported to the Golgi apparatus (Asker et al., 1998), where the TRR domains of the mucin dimers are glycosylated before further assembly into trimers in the trans-Golgi network (Godl et al., 2002) and packaging into goblet cell granules in a pH- and calcium-dependent manner (Ambort et al., 2012). As a monomer, fully glycosylated MUC2 exhibits a size of $2.5 \mathrm{MDa}$, whereas extensive polymerization in the granules may lead to sizes greater than $100 \mathrm{MDa}$ (Johansson et al., 2008). Following degranulation of the mucin at the mucosa, the densely packed mucins are hydrated and expand into extensive polymers, resulting in a physical barrier at the epithelium that entraps invading microorganisms (Perez-Vilar et al., 2006, Verdugo, 2012). Moreover, the mucus gel provides a matrix for antimicrobial molecules, which are mainly produced by Paneth cells. Direct interactions with mucins can facilitate the diffusion of these antimicrobial molecules (Linden et al., 2008); however, additional studies addressing the interactions of mucins and host-defense peptides/proteins are needed to understand how the mucin environment influences the function of these biomolecules. In addition to their protective and lubricating properties, mucins can be a nutritional source for microorganisms. Some commensal intestinal bacteria, including Bacteroidetes, are mucolytic and use mucin glycoproteins as an energy source. Moreover, these bacteria provide substrates for other 
bacteria in the outer mucus layer by degrading the mucins (Sonnenburg et al., 2005, Png et al., 2010). Therefore, mucins have been proposed to play an important role in shaping microbial communities at the intestinal mucosa. Recent studies suggest the correlation between changes in mucin glycosylation profile and deviations of overall microbial community ecology as well as altered abundances of specific microbes (Kashyap et al., 2013, Sommer et al., 2014).

A recent study reported that mucins suppress the virulence traits of the opportunistic human fungal pathogen Candida albicans (Perlroth et al., 2007, Kavanaugh et al., 2014), providing evidence for an unappreciated role of mucins in the host/microbe interaction. This organism is a gut commensal, but it can become virulent under certain conditions (e.g. immunocompromised host) (Sardi et al., 2013). Microscopy studies of $C$. albicans cultured in the presence and absence of mucins revealed that the mucins induce a new oval-shaped morphology in $C$. albicans. Moreover, several genes that are important in steps critical for virulence - adhesion, filamentation, and biofilm formation - were downregulated in the presence of mucins. These results indicate that, that in addition to providing a physical barrier, mucins affect the physiology of $C$. albicans and help to keep this fungal species in the commensal state in the gut. Further investigations shall inform whether this remarkable property of mucins is generalizable to other microbes as well as to other classes of mucins.

\section{Secretory Immunoglobulin A (slgA)}

Secretroy $\operatorname{Ig} \mathrm{A}(\mathrm{s} \operatorname{Ig} \mathrm{A})$ is an abundant antibody that is produced and released by plasma cells. It dominates humoral immunity at the intesitnal mucosa (Macpherson et al., 2012). One sIgA molecule is about $400 \mathrm{kDa}$ and is composed of two four-chain untis of IgA, one $\mathrm{J}$ chain, and one secretory component (Figure 8) (Woof and Russell, 2011). Due to its polymeric nature and multivalency, sIgA primarily protects mucosal surfaces by noncovalently cross-linking microorganisms or macromolecules. This phenomeon (i) blocks microbial adhesins, sterically hindering interactions of the adhesins with the epithelium, and (ii) inhibits microbial motility and facilitates microbial entrapment in mucus (Mantis et al., 2011). Ultimately, sIgA promotes the clearance of these entrapped microbes by peristalsis or mucocilary movement. The overall process is known as immune exclusion (Stokes et al., 1975). In the lamina propria, polymeric sIgA also binds and excretes antigens back to the lumen using polymeric Ig receptor-mediated transcytosis across epithelial cells (Robinson et al., 2001). In additon, sIgA responses are not only specific to pathogens, but also to commensal microorganisms residing in the gut (Lindner et al., 2012). It has been proposed that coating of commensal bacteria by sIgA may lead to a different recognition by epithelial cells and dendritic cells as compared to pathogens, and hence faciliate the discrimmination between symbionts and pathogens by the host (Sansonetti, 2011). Indeed, recent studies indicate that $\operatorname{sgA}$ plays a role in shaping and maintaining the gut microbiota from birth to adulthood (Pabst et al., 2016). Neutralizaton of bacterial toxins is another function of IgA (Vaerman et al., 1985, Forbes et al., 2011). For example, binding of a murine IgA monoclonal antibodies to the $\mathrm{O}$ antigen of Shigella flexneri suppressed the activity of the bacterial type 3 secretion system that is necessary for $S$. flexneri to invade into intestinal epithelial cells (Forbes et al., 2011). 


\section{Summary and Perspectives}

In this review, we provide an overview of abundant intestinal biomolecules - mucins, lectins, sIgA and HD6 - that contribute to host defense by binding microbes and preventing these microbes from invading the epithelium. This general mechanism contrasts the cell killing mechanisms displayed by many antimicrobial peptides, and further studies are needed to elucidate the mechanisms by which these microbe-binding molecules provide barrier function. We note here that the vast majority of investigations reported to date have evaluated these biomolecules on a case-by-case basis. Although these molecules may contribute to mucosal immunity at different locales or during different stages of infection, it is possible that unrecognized synergies occur, and our current understanding of whether these immune factors cooperate to protect the intestinal epithelium is limited. Rich avenues for further studies involve elucidating how the interplay between these host-defense factors, as well as others, influences intestinal homeostasis and the host response to infection. Such investigations will benefit from enhanced understanding at the molecular level for how these biomolecules interact with microbes. The consequences of microbe-binding interactions by these biomolecules on microbial physiology, metabolism, and virulence also warrant consideration. Lastly, our appreciation for how the commensal microbiota contributes to human helath and disease is growing at a rapid pace. More information about these processes may provide new insights into host-commensal interactions at the intestinal mucosa and may illuminate how to approach disorders that result from dysbiosis, including inflammatory conditions of the bowel such as Crohn's disease.

\section{Acknowledgments}

Declaration of Interest Statement

We thank the NIH (Grant DP2OD007045 from the Office of the Director) and the MIT Department of Chemistry for supporting our research on human enteric a-defensin peptides. PC is a recipient of a Royal Thai Government Fellowship.

\section{References}

Ambort D, Johansson MEV, Gustafsson JK, Nilsson HE, Ermund A, Johansson BR, Koeck PJB, Hebert H, Hansson GC. Calcium and $\mathrm{pH}$-dependent packing and release of the gel-forming MUC2 mucin. Proc. Natl. Acad. Sci. U. S. A. 2012; 109:5645-5650. [PubMed: 22451922]

Asker N, Axelsson MAB, Olofsson S-O, Hansson GC. Dimerization of the human MUC2 mucin in the endoplasmic reticulum is followed by a $\mathrm{N}$-glycosylation-dependent transfer of the mono- and dimers to the Golgi apparatus. J. Biol. Chem. 1998; 273:18857-18863. [PubMed: 9668061]

Ayabe T, Satchell DP, Wilson CL, Parks WC, Selsted ME, Ouellette AJ. Secretion of microbicidal adefensins by intestinal Paneth cells in response to bacteria. Nat. Immunol. 2000; 1:113-118. [PubMed: 11248802]

Bergstrom KSB, Xia L. Mucin-type $O$-glycans and their roles in intestinal homeostasis. Glycobiology. 2013; 23:1026-1037. [PubMed: 23752712]

Bevins CL, Salzman NH. Paneth cells, antimicrobial peptides and maintenance of intestinal homeostasis. Nat. Rev. Microbiol. 2011; 9:356-368. [PubMed: 21423246]

Broekaert WF, Terras FRG, Cammue BPA, Osborn RW. Plant defensins: novel antimicrobial peptides as components of the host defense system. Plant Physiol. 1995; 108:1353-1358. [PubMed: 7659744] 
Cash HL, Whitham CV, Behrendt CL, Hooper LV. Symbiotic bacteria direct expression of an intestinal bactericidal lectin. Science. 2006; 313:1126-1130. [PubMed: 16931762]

Cerovic V, Bain CC, Mowat AM, Milling SWF. Intestinal macrophages and dendritic cells: what's the difference? Trends Immunol. 2014; 35:270-277. [PubMed: 24794393]

Chairatana P, Chu H, Castillo PA, Shen B, Bevins CL, Nolan EM. Proteolysis triggers self-assembly and unmasks innate immune function of a human a-defensin peptide. Chem. Sci. 2016; 7:17381752. [PubMed: 27076903]

Chairatana P, Nolan EM. Molecular basis for self-assembly of a human host-defense peptide that entraps bacterial pathogens. J. Am. Chem. Soc. 2014; 136:13267-13276. [PubMed: 25158166]

Cheng H. Origin, differentiation and renewal of the four main epithelial cell types in the mouse small intestine. II. Mucous cells. Am. J. Anat. 1974a; 141:481-501. [PubMed: 4440633]

Cheng H. Origin, differentiation and renewal of the four main epithelial cell types in the mouse small intestine. IV. Paneth cells. Am. J. Anat. 1974b; 141:521-535. [PubMed: 4440634]

Cheng H, Leblond CP. Origin, differentiation and renewal of the four main epithelial cell types in the mouse small intestine. I. Columnar cell. Am. J. Anat. 1974a; 141:461-479. [PubMed: 4440632]

Cheng H, Leblond CP. Origin, differentiation and renewal of the four main epithelial cell types in the mouse small intestine. III. Entero-endocrine cells. Am. J. Anat. 1974b; 141:503-519. [PubMed: 4216261]

Chileveru HR, Lim SA, Chairatana P, Wommack AJ, Chiang I-L, Nolan EM. Visualizing attack of Escherichia coli by the antimicrobial peptide human defensin 5. Biochemistry. 2015; 54:17671777. [PubMed: 25664683]

Choi S-M, McAleer J, Zheng M, Pociask DA, Kaplan MH, Qin S, Reinhart TA, Kolls JK. Innate Stat3mediated induction of the antimicrobial protein Reg $3 \gamma$ is required for host defense against MRSA pneumonia. J. Exp. Med. 2013; 210:551-561. [PubMed: 23401489]

Christa L, Carnot F, Simon M-T, Levavasseur F, Stinnakre M-G, Lasserre C, Thepot D, Clement B, Devinoy E, Bréchot C. HIP/PAP is an adhesive protein expressed in hepatocarcinoma, normal Paneth, and pancreatic cells. Am. J. Physiol. 1996; 271:G993-G1002. [PubMed: 8997243]

Chu H, Pazgier M, Jung G, Nuccio S-P, Castillo PA, de Jong MF, Winter MG, Winter SE, Wehkamp J, Shen B, Salzman NH, Underwood MA, Tsolis RM, Young GM, Lu W, Lehrer RI, Bäumler AJ, Bevins CL. Human a-defensin 6 promotes mucosal innate immunity through self-assembled peptide nanonets. Science. 2012; 337:477-481. [PubMed: 22722251]

Clevers HC, Bevins CL. Paneth cells: maestros of the small intestinal crypts. Annu. Rev. Physiol. 2013; 75:289-311. [PubMed: 23398152]

Conibear AC, Rosengren KJ, Harvey PJ, Craik DJ. Structural characterization of the cyclic cystine ladder motif of $\theta$-defensins. Biochemistry. 2012; 51:9718-9726. [PubMed: 23148585]

Corfield AP. Mucins: a biologically relevant glycan barrier in mucosal protection. Biochim. Biophys. Acta. 2015; 1850:236-252. [PubMed: 24821013]

Costello EK, Lauber CL, Hamady M, Fierer N, Gordon JI, Knight R. Bacterial community variation in human body habitats across space and time. Science. 2009; 326:1694-1697. [PubMed: 19892944]

Cunliffe RN, Rose FRaJ, Keyte J, Abberley L, Chan WC, Mahida YR. Human defensin 5 is stored in precursor form in normal Paneth cells and is expressed by some villous epithelial cells and by metaplastic Paneth cells in the colon in inflammatory bowel disease. Gut. 2001; 48:176-185. [PubMed: 11156637]

Destoumieux D, Bulet P, Loew D, Van Dorsselaer A, Rodriguez J, Bachère E. Penaeidins, a new family of antimicrobial peptides isolated from the shrimp Penaeus vannamei (decapoda). J. Biol. Chem. 1997; 272:28398-28406. [PubMed: 9353298]

Dommett R, Zilbauer M, George JT, Bajaj-Elliott M. Innate immune defence in the human gastrointestinal tract. Mol. Immunol. 2005; 42:903-912. [PubMed: 15829280]

Ericksen B, Wu Z, Lu W, Lehrer RI. Antibacterial activity and specificity of the six human adefensins. Antimicrob. Agents Chemother. 2005; 49:269-275. [PubMed: 15616305]

Evans EW, Beach GG, Wunderlich J, Harmon BG. Isolation of antimicrobial peptides from avian heterophils. J. Leukoc. Biol. 1994; 56:661-665. [PubMed: 7964174] 
Forbes SJ, Bumpus T, McCarthy EA, Corthésy B, Mantis NJ. Transient suppression of Shigella flexneri type 3 secretion by a protective $O$-antigen-specific monoclonal IgA. mBio. 2011; 2:e00042-e00011. [PubMed: 21610121]

Furci L, Baldan R, Bianchini V, Trovato A, Ossi C, Cichero P, Cirillo DM. New role for human adefensin 5 in the fight against hypervirulent Clostridium difficile strains. Infect. Immun. 2015; 83:986-995. [PubMed: 25547793]

Furness JB, Rivera LR, Cho H-J, Bravo DM, Callaghan B. The gut as a sensory organ. Nat. Rev. Gastroenterol. Hepatol. 2013; 10:729-740. [PubMed: 24061204]

Ganz T. Defensins : antimicrobial peptides of innate immunity. Nat. Rev. Immunol. 2003; 3:710-720. [PubMed: 12949495]

Ghoos Y, Vantrappen G. The cytochemical localization of lysozyme in Paneth cell granules. Histochem. J. 1971; 3:175-178. [PubMed: 4106573]

Ghosh D, Porter E, Shen B, Lee SK, Wilk D, Drazba J, Yadav SP, Crabb JW, Ganz T, Bevins CL. Paneth cell trypsin is the processing enzyme for human defensin-5. Nature. 2002; 3:583-590.

Godl K, Johansson MEV, Lidell ME, Mörgelin M, Karlsson H, Olson FJ, Gum JR Jr, Kim YS, Hansson GC. The N terminus of the MUC2 mucin forms trimers that are held together within a trypsin-resistant core fragment. J. Biol. Chem. 2002; 277:47248-47256. [PubMed: 12374796]

Harwig SSL, Swiderek KM, Kokryakov VN, Tan L, Lee TD, Panyutich EA, Aleshina GM, Shamova OV, Lehrer RI. Gallinacins: cysteine-rich antimicrobial peptides of chicken leukocytes. FEBS Lett. 1994; 342:281-285. [PubMed: 8150085]

Hattrup CL, Gendler SJ. Structure and function of the cell surface (tethered) mucins. Annu Rev Physiol. 2008; 70:431-457. [PubMed: 17850209]

Hill CP, Yee J, Selsted ME, Eisenberg D. Crystal structure of defensin HNP-3, an amphiphilic dimer: mechanisms of membrane permeabilization. Science. 1991; 251:1481-1485. [PubMed: 2006422]

Hooper LV, Littman DR, Macpherson AJ. Interactions between the microbiota and the immune system. Science. 2012; 336:1268-1273. [PubMed: 22674334]

Hoover DM, Chertov O, Lubkowski J. The structure of human $\beta$-defensin-1. New insights into structural properties of $\beta$-defensins. J. Biol. Chem. 2001; 276:39021-39026. [PubMed: 11486002]

Johansson MEV, Phillipson M, Petersson J, Velcich A, Holm L, Hansson GC. The inner of the two Muc2 mucin-dependent mucus layers in colon is devoid of bacteria. Proc. Natl. Acad. Sci. U. S. A. 2008; 105:15064-15069. [PubMed: 18806221]

Jonckheere N, Van Seuningen I. The membrane-bound mucins: from cell signalling to transcriptional regulation and expression in epithelial cancers. Biochimie. 2010; 92:1-11. [PubMed: 19818375]

Jones DE, Bevins CL. Paneth cells of the human small intestine express an antimicrobial peptide gene. J. Biol. Chem. 1992; 267:23216-23225. [PubMed: 1429669]

Jones DE, Bevins CL. Defensin-6 mRNA in human Paneth cells: implications for antimicrobial peptides in host defense of the human bowel. FEBS Lett. 1993; 315:187-192. [PubMed: 8417977]

Kashyap PC, Marcobal A, Ursell LK, Smits SA, Sonnenburg ED, Costello EK, Higginbottom SK, Domino SE, Holmes SP, Relman DA, Knight R, Gordon JI, Sonnenburg JL. Genetically dictated change in host mucus carbohydrate landscape exerts a diet-dependent effect on the gut microbiota. Proc. Natl. Acad. Sci. U. S. A. 2013; 110:17059-17064. [PubMed: 24062455]

Kaur S, Kumar S, Momi N, Sasson AR, Batra SK. Mucins in pancreatic cancer and its microenvironment. Nat. Rev. Gastroenterol. Hepatol. 2013; 10:607-620. [PubMed: 23856888]

Kavanaugh NL, Zhang AQ, Nobile CJ, Johnson AD, Ribbeck K. Mucins suppress virulence traits of Candida albicans. mBio. 2014; 5:e01911-e01914. [PubMed: 25389175]

Kim JJ, Khan WI. Goblet cells and mucins: role in innate defense in enteric infections. Pathogens. 2013; 2:55-70. [PubMed: 25436881]

Kiyohara H, Egami H, Shibata Y, Murata K, Ohshima S, Ogawa M. Light microscopic immunohistochemical analysis of the distribution of group II phospholipase $\mathrm{A}_{2}$ in human digestive organs. J. Histochem. Cytochem. 1992; 40:1659-1664. [PubMed: 1431054]

Kudryashova E, Quintyn R, Seveau S, Lu W, Wysocki VH, Kudryashov DS. Human defensins facilitate local unfolding of thermodynamically unstable regions of bacterial protein toxins. Immunity. 2014; 41:709-721. [PubMed: 25517613] 
Lasserre C, Colnot C, Bréchot C, Poirier F. HIP/PAP gene, encoding a C-type lectin overexpressed in primary liver cancer, is expressed in nervous system as well as in intestine and pancreas of the postimplantation mouse embryo. Am. J. Pathol. 1999; 154:1601-1610. [PubMed: 10329612]

Lehotzky RE, Partch CL, Mukherjee S, Cash HL, Goldman WE, Gardner KH, Hooper LV. Molecular basis for peptidoglycan recognition by a bactericidal lectin. Proc. Natl. Acad. Sci. U. S. A. 2010; 107:7722-7727. [PubMed: 20382864]

Lehrer RI, Ganz T. Antimicrobial peptides in mammalian and insect host defence. Curr. Opin. Immunol. 1999; 11:23-27. [PubMed: 10047545]

Lehrer RI, Jung G, Ruchala P, Andre S, Gabius HJ, Lu W. Multivalent binding of carbohydrates by the human a-defensin, HD5. J. Immunol. 2009; 183:480-490. [PubMed: 19542459]

Lehrer RI, Lu W. a-Defensins in human innate immunity. Immunol. Rev. 2012; 245:84-112. [PubMed: 22168415]

Linden SK, Sutton P, Karlsson NG, Korolik V, McGuckin MA. Mucins in the mucosal barrier to infection. Mucosal Immunol. 2008; 1:183-197. [PubMed: 19079178]

Lindner C, Wahl B, Föhse L, Suerbaum S, Macpherson AJ, Prinz I, Pabst O. Age, microbiota, and T cells shape diverse individual IgA repertoires in the intestine. J. Exp. Med. 2012; 209:365-377. [PubMed: 22249449]

Linzmeier R, Ho CH, Hoang BV, Ganz T. A 450-kb contig of defensin genes on human chromosome 8p23. Gene. 1999; 233:205-211. [PubMed: 10375637]

Litman GW, Rast JP, Fugmann SD. The origins of vertebrate adaptive immunity. Nat. Rev. Immunol. 2010; 10:543-553. [PubMed: 20651744]

Loonen LMP, Stolte EH, Jaklofsky MTJ, Meijerink M, Dekker J, van Baarlen P, Wells JM. REG3 $\gamma$ deficient mice have altered mucus distribution and increased mucosal inflammatory responses to the microbiota and enteric pathogens in the ileum. Mucosal Immunol. 2014; 7:939-947. [PubMed: 24345802]

Macpherson AJ, Geuking MB, McCoy KD. Homeland security: IgA immunity at the frontiers of the body. Trends Immunol. 2012; 33:160-167. [PubMed: 22410243]

Mantis NJ, Rol N, Corthésy B. Secretory IgA's complex roles in immunity and mucosal homeostasis in the gut. Mucosal Immunol. 2011; 4:603-611. [PubMed: 21975936]

McGuckin MA, Lindén SK, Sutton P, Florin TH. Mucin dynamics and enteric pathogens. Nat. Rev. Microbiol. 2011; 9:265-278. [PubMed: 21407243]

Moser S, Chileveru HR, Tomaras J, Nolan EM. A bacterial mutant library as a tool to study the attack of a defensin peptide. Chembiochem. 2014; 15:2684-2688. [PubMed: 25430675]

Mukherjee S, Zheng H, Derebe MG, Callenberg KM, Partch CL, Rollins D, Propheter DC, Rizo J, Grabe M, Jiang Q-X, Hooper LV. Antibacterial membrane attack by a pore-forming intestinal Ctype lectin. Nature. 2014; 505:103-107. [PubMed: 24256734]

Ouellette AJ, Darmoul D, Tran D, Huttner KM, Yuan J, Selsted ME. Peptide localization and gene structure of cryptdin 4, a differentially expressed mouse paneth cell a-defensin. Infect. Immun. 1999; 67:6643-6651. [PubMed: 10569786]

Pabst O, Cerovic V, Hornef M. Secretory IgA in the coordination of establishment and maintenance of the microbiota. Trends Immunol. 2016; 37:287-296. [PubMed: 27066758]

Parkin J, Cohen B. An overview of the immune system. Lancet. 2001; 357:1777-1789. [PubMed: 11403834]

Pazgier M, Wei G, Ericksen B, Jung G, Wu Z, de Leeuw E, Yuan W, Szmacinski H, Lu W-Y, Lubkowski J, Lehrer RI, Lu W. Sometimes it takes two to tango: contributions of dimerization to functions of human a-defensin HNP1 peptide. J Biol Chem. 2012; 287:8944-8953. [PubMed: 22270360]

Perez-Vilar J, Mabolo R, Mcvaugh CT, Bertozzi CR, Boucher RC. Mucin granule intraluminal organization in living mucous/goblet cells roles of protein post-translational modifications and secretion. J. Biol. Chem. 2006; 281:4844-4855. [PubMed: 16377632]

Perlroth J, Choi B, Spellberg B. Nosocomial fungal infections: epidemiology, diagnosis, and treatment. Med. Mycol. 2007; 45:321-346. [PubMed: 17510856]

Peterson LW, Artis D. Intestinal epithelial cells: regulators of barrier function and immune homeostasis. Nat. Rev. Immunol. 2014; 14:141-153. [PubMed: 24566914] 
Png CW, Lindén SK, Gilshenan KS, Zoetendal EG, McSweeney CS, Sly LI, McGuckin MA, Florin THJ. Mucolytic bacteria with increased prevalence in IBD mucosa augment in vitro utilization of mucin by other bacteria. Am. J. Gastroenterol. 2010; 105:2420-2428. [PubMed: 20648002]

Porter EM, Bevins CL, Ghosh D, Ganz T. The multifaceted Paneth cell. Cell. Mol. Life Sci. 2002; 59:156-170. [PubMed: 11846026]

Porter EM, Liu L, Oren A, Anton PA, Ganz T. Localization of human intestinal defensin 5 in Paneth cell granules. Infect. Immun. 1997a; 65:2389-2395. [PubMed: 9169779]

Porter EM, van Dam E, Valore EV, Ganz T. Broad-spectrum antimicrobial activity of human intestinal defensin 5. Infect. Immun. 1997b; 65:2396-2401. [PubMed: 9169780]

Qin J, Li R, Raes J, Arumugam M, Burgdorf KS, Manichanh C, Nielsen T, Pons N, Levenez F, Yamada T, Mende DR, Li J, Xu J, Li S, Li D, Cao J, Wang B, Liang H, Zheng H, Xie Y, Tap J, Lepage P, Bertalan M, Batto J-M, Hansen T, Le Paslier D, Linneberg A, Nielsen HB, Pelletier E, Renault P, Sicheritz-Ponten T, Turner K, Zhu H, Yu C, Li S, Jian M, Zhou Y, Li Y, Zhang X, Li S, Qin N, Yang H, Wang J, Brunak S, Doré J, Guarner F, Kristiansen K, Pedersen O, Parkhill J, Weissenbach J, Consortium M, Bork P, Ehrlilch SD, Wang J. A human gut microbial gene catalogue established by metagenomic sequencing. Nature. 2010; 464:59-65. [PubMed: 20203603]

Quayle AJ, Porter EM, Nussbaum AA, Wang YM, Brabec C, Yip K-P, Mok SC. Gene expression, immunolocalization, and secretion of human defensin-5 in human female reproductive tract. Am. J. Pathol. 1998; 152:1247-1258. [PubMed: 9588893]

Rajabi M, Ericksen B, Wu X, de Leeuw E, Zhao L, Pazgier M, Lu W. Functional determinants of human enteric a-defensin HD5: crucial role for hydrophobicity at dimer interface. J. Biol. Chem. 2012; 287:21615-21627. [PubMed: 22573326]

Robinson JK, Blanchard TG, Levine AD, Emancipator SN, Lamm ME. A mucosal IgA-mediated excretory immune system in vivo. J. Immunol. 2001; 166:3688-3692. [PubMed: 11238608]

Salzman NH, Ghosh D, Huttner KM, Paterson Y, Bevins CL. Protection against enteric salmonellosis in transgenic mice expressing a human intestinal defensin. Nature. 2003; 442:522-526.

Salzman NH, Hung K, Haribhai D, Chu H, Karlsson-Sjöberg J, Amir E, Teggatz P, Barman M, Hayward M, Eastwood D, Stoel M, Zhou Y, Sodergren E, Weinstock GM, Bevins CL, Williams $\mathrm{CB}, \mathrm{Bos}$ NA. Enteric defensins are essential regulators of intestinal microbial ecology. Nat. Immunol. 2010; 11:76-83. [PubMed: 19855381]

Sansonetti PJ. To be or not to be a pathogen: that is the mucosally relevant question. Mucosal Immunol. 2011; 4:8-14. [PubMed: 21150896]

Santaolalla R, Fukata M, Abreu MT. Innate immunity in the small intestine. Curr. Opin. Gastroenterol. 2011; 27:125-131. [PubMed: 21248635]

Sardi JCO, Scorzoni L, Bernardi T, Fusco-Almeida AM, Mendes Giannini MJS. Candida species: current epidemiology, pathogenicity, biofilm formation, natural antifungal products and new therapeutic options. J. Med. Microbiol. 2013; 62:10-24. [PubMed: 23180477]

Satoh Y, Habara Y, Ono K, Kanno T. Carbamylcholine- and catecholamine-induced intracellular calcium dynamics of epithelial cells in mouse ileal crypts. Gastroenterol. 1995; 108:1345-1356.

Snoeck V, Goddeeris B, Cox E. The role of enterocytes in the intestinal barrier function and antigen uptake. Microb. Infect. 2005; 7:997-1004.

Sommer F, Adam N, Johansson MEV, Xia L, Hansson GC, Bäckhed F. Altered mucus glycosylation in core $1 O$-glycan-deficient mice affects microbiota composition and intestinal architecture. PLoS One. 2014; 9:e85254. [PubMed: 24416370]

Sonnenburg JL, Xu J, Leip DD, Chen C-H, Westover BP, Weatherford J, Buhler JD, Gordon JI. Glycan foraging in vivo by an intestine-adapted bacterial symbiont. Science. 2005; 307:1955-1959. [PubMed: 15790854]

Specian RD, Oliver MG. Functional biology of intestinal goblet cells. Am. J. Physiol. 1991; 260:C183-C193. [PubMed: 1996606]

Spencer JD, Hains DS, Porter E, Bevins CL, DiRosario J, Becknell B, Wang H, Schwaderer AL. Human alpha defensin 5 expression in the human kidney and urinary tract. PLoS One. 2012; 7:e31712. [PubMed: 22359618] 
Stokes CR, Soothill JF, Turner MW. Immune exclusion is a function of IgA. Nature. 1975; 255:745746. [PubMed: 1169692]

Szyk A, Wu Z, Tucker K, Yang D, Lu W, Lubkowski J. Crystal structures of human a-defensins HNP4, HD5, and HD6. Prot. Sci. 2006; 15:2749-2760.

Tang Y-Q, Yuan J, Ösapay G, Ösapay K, Tran D, Miller CJ, Ouellette AJ, Selsted ME. A cyclic antimicrobial peptide produced in primate leukocytes by the ligation of two truncated a-defensins. Science. 1999; 286:498-502. [PubMed: 10521339]

Thomassin J-L, Lee MJ, Brannon JR, Sheppard DC, Gruenheid S, Le Moual H. Both group 4 capsule and lipopolysaccharide O-antigen contribute to enteropathogenic Escherichia coli resistance to human a-defensin 5. PLoS One. 2013; 8:e82475. [PubMed: 24324796]

Thomsen T, Schlosser A, Holmskov U, Sorensen GL. Ficolins and FIBCD1: soluble and membrane bound pattern recognition molecules with acetyl group selectivity. Mol. Immunol. 2011; 48:369381. [PubMed: 21071088]

Thornton DJ, Rousseau K, McGuckin MA. Structure and function of the polymeric mucins in airways mucus. Annu Rev Physiol. 2008; 70:459-486. [PubMed: 17850213]

Trabi M, Schirra HJ, Craik DJ. Three-dimensional structure of RTD-1, a cyclic antimicrobial defensin from Rhesus macaque leukocytes. Biochemistry. 2001; 40:4211-4221. [PubMed: 11284676]

Tsuji S, Uehori J, Matsumoto M, Suzuki Y, Matsuhisa A, Toyoshima K, Seya T. Human intelectin is a novel soluble lectin that recognizes galactofuranose in carbohydrate chains of bacterial cell wall. J. Biol. Chem. 2001; 276:23456-23463. [PubMed: 11313366]

Vaerman JP, Derijck-Langendries A, Rits M, Delacroix D. Neutralization of cholera toxin by rat bile secretory IgA antibodies. Immunology. 1985; 54:601-603. [PubMed: 3918935]

Verdugo P. Supramolecular dynamics of mucus. Cold Spring Harb. Perspect. Med. 2012; 2:1-15.

Voehringer D, Stanley SA, Cox JS, Completo GC, Lowary TL, Locksley RM. Nippostrongylus brasiliensis: identification of intelectin-1 and -2 as Stat6-dependent genes expressed in lung and intestine during infection. Exp. Parasitol. 2007; 116:458-466. [PubMed: 17420014]

Wanniarachchi YA, Kaczmarek P, Wan A, Nolan EM. Human defensin 5 disulfide array mutants: disulfide bond deletion attenuates antibacterial activity against Staphylococcus aureus. Biochemistry. 2011; 50:8005-8017. [PubMed: 21861459]

Wehkamp J, Chu H, Shen B, Feathers RW, Kays RJ, Lee SK, Bevins CL. Paneth cell antimicrobial peptides: topographical distribution and quantification in human gastrointestinal tissues. FEBS Lett. 2006; 580:5344-5350. [PubMed: 16989824]

Wehkamp J, Stange EF. Paneth's disease. J. Crohn's Colitis. 2010; 4:523-531. [PubMed: 21122555]

Wei G, de Leeuw E, Pazgier M, Yuan W, Zou G, Wang J, Ericksen B, Lu W-Y, Lehrer RI, Lu W. Through the looking glass, mechanistic insights from enantiomeric human defensins. J. Biol. Chem. 2009; 284:29180-29192. [PubMed: 19640840]

Weis WI, Taylor ME, Drickamer K. The C-type lectin superfamily in the immune system. Immunol. Rev. 1998; 163:19-34. [PubMed: 9700499]

Wesener DA, Wangkanont K, McBride R, Song X, Kraft MB, Hodges HL, Zarling LC, Splain RA, Smith DF, Cummings RD, Paulson JC, Forest KT, Kiessling LL. Recognition of microbial glycans by human intelectin-1. Nat. Struct. Mol. Biol. 2015; 22:603-610. [PubMed: 26148048]

Wommack AJ, Robson SA, Wanniarachchi YA, Wan A, Turner CJ, Wagner G, Nolan EM. NMR solution structure and condition-dependent oligomerization of the antimicrobial peptide human defensin 5. Biochemistry. 2012; 51:9624-9637. [PubMed: 23163963]

Wommack AJ, Ziarek JJ, Tomaras J, Chileveru HR, Zhang Y, Wagner G, Nolan EM. Discovery and characterization of a disulfide-locked $\mathrm{C}_{2}$-symmetric defensin peptide. J. Am. Chem. Soc. 2014; 136:13494-13497. [PubMed: 25181039]

Woof JM, Russell MW. Structure and function relationships in IgA. Mucosal Immunol. 2011; 4:590597. [PubMed: 21937984]

Zhao L, Ericksen B, Wu X, Zhan C, Yuan W, Li X, Pazgier M, Lu W. Invariant gly residue is important for a-defensin folding, dimerization, and function: a case study of the human neutrophil adefensin HNP1. J Biol Chem. 2012; 287:18900-18912. [PubMed: 22496447]

Zhao L, Lu W. Defensins in innate immunity. Curr. Opin. Hematol. 2014; 21:37-42. [PubMed: 24275690] 
Zhu S. Discovery of six families of fungal defensin-like peptides provides insights into origin and evolution of the CSa $\beta$ defensins. Mol. Immunol. 2008; 45:828-838. [PubMed: 17675235]

Zou J, Mercier C, Koussounadis A, Secombes C. Discovery of multiple beta-defensin like homologues in teleost fish. Mol. Immunol. 2007; 44:638-647. [PubMed: 16540171] 


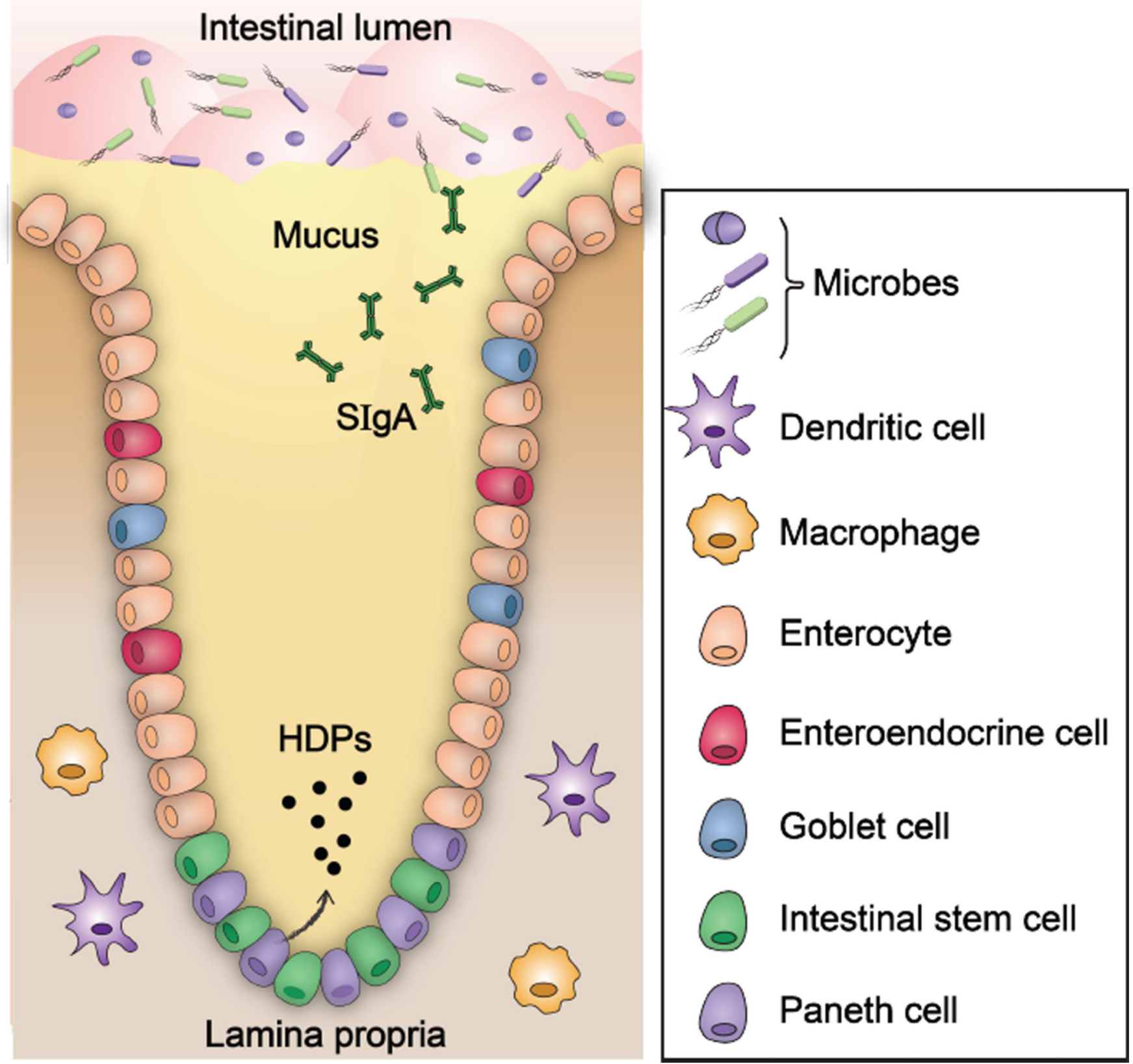

Figure 1.

The physical and chemical barriers in a crypt of small intestine. Intestinal epithelial cells form physical and chemical barriers that segregate the luminal microbial community and the mucosal immune system. HDP = host-defense peptide; $\operatorname{sIg} \mathrm{A}=$ secretory immunoglobulin A. A color version of the figure is available online. 

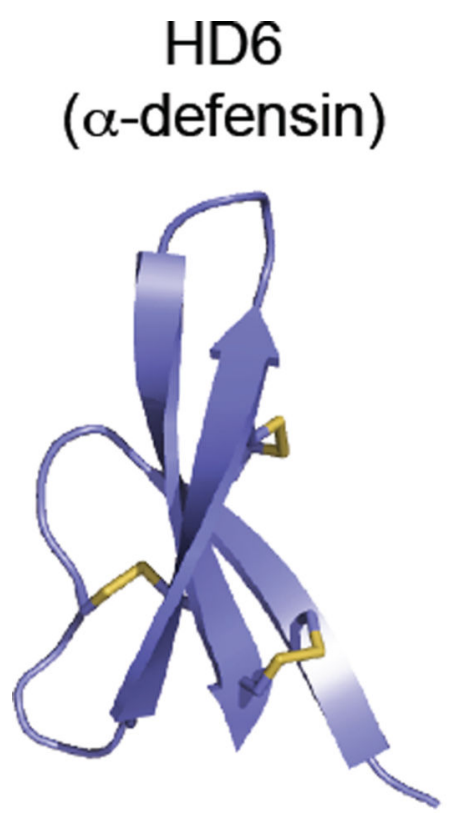

\section{HBD1}

( $\beta$-defensin)

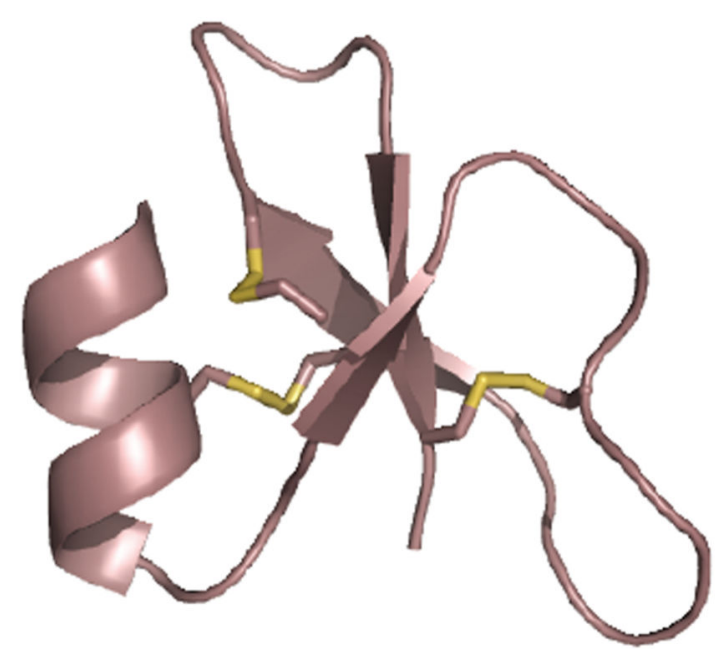

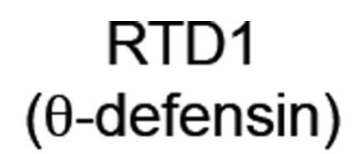

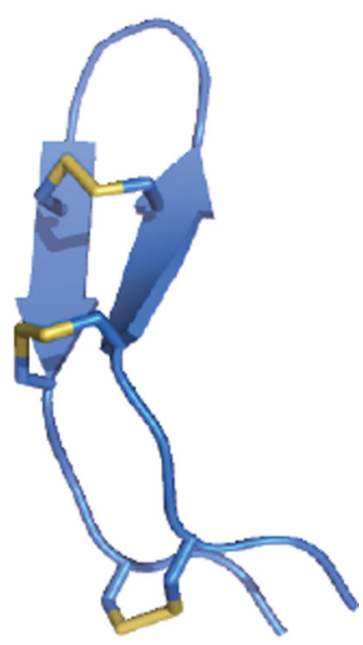

Figure 2.

Primary sequences and X-ray crystal structures of select defensins. HD6 (PDB 1ZMQ (Szyk et al., 2006)), HBD1 (PDB 1IJV (Hoover et al., 2001)), and RTD1 (PDB 1HVZ (Trabi et al., 2001)) are representatives of $\alpha_{-}, \beta-$, and $\theta$-defensin, respectively. The disulfide linkages are shown in yellow. A color version of the figure is available online. 


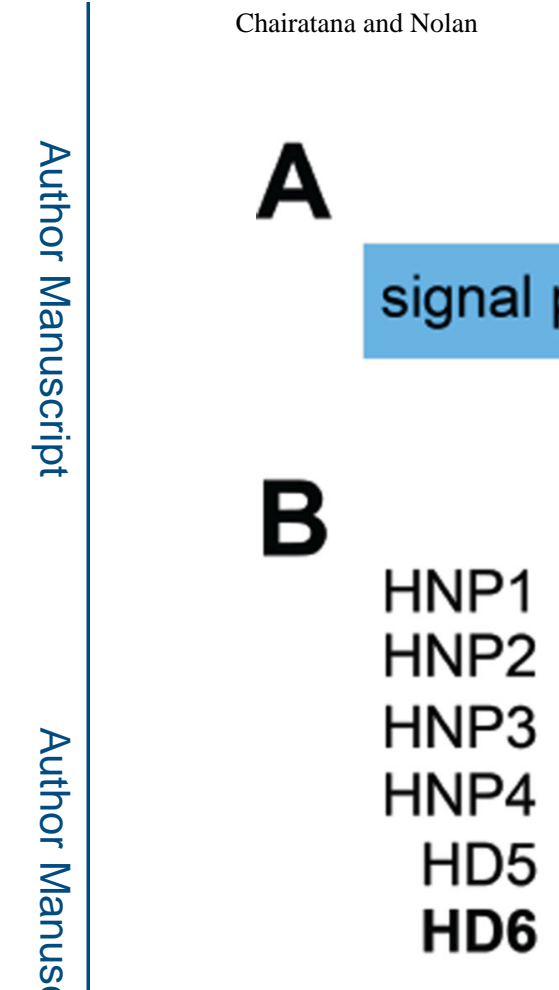

protease

$\checkmark$

\section{signal peptide \\ pro domain \\ mature defensin}

HNP1

HNP2

HNP3

HNP4

HD5

Crit Rev Biochem Mol Biol. Author manuscript; available in PMC 2017 February 01.

\section{Figure 3.}

Defensins are expressed as prepropeptides and exhibit several conserved features. (A) A cartoon represents a prepropeptide. The black arrow indicates the position where a protease cleaves and releases a mature defensin. (B) Amino acid sequences of mature a-defensins in which conserved features are highlighted: cysteine residues and regiospecific disulfide linkages are shown in red, a salt bridge between Arg and Glu residues is shown in blue, a Gly residue in a GXC motif is shown green. A color version of the figure is available online. 
1
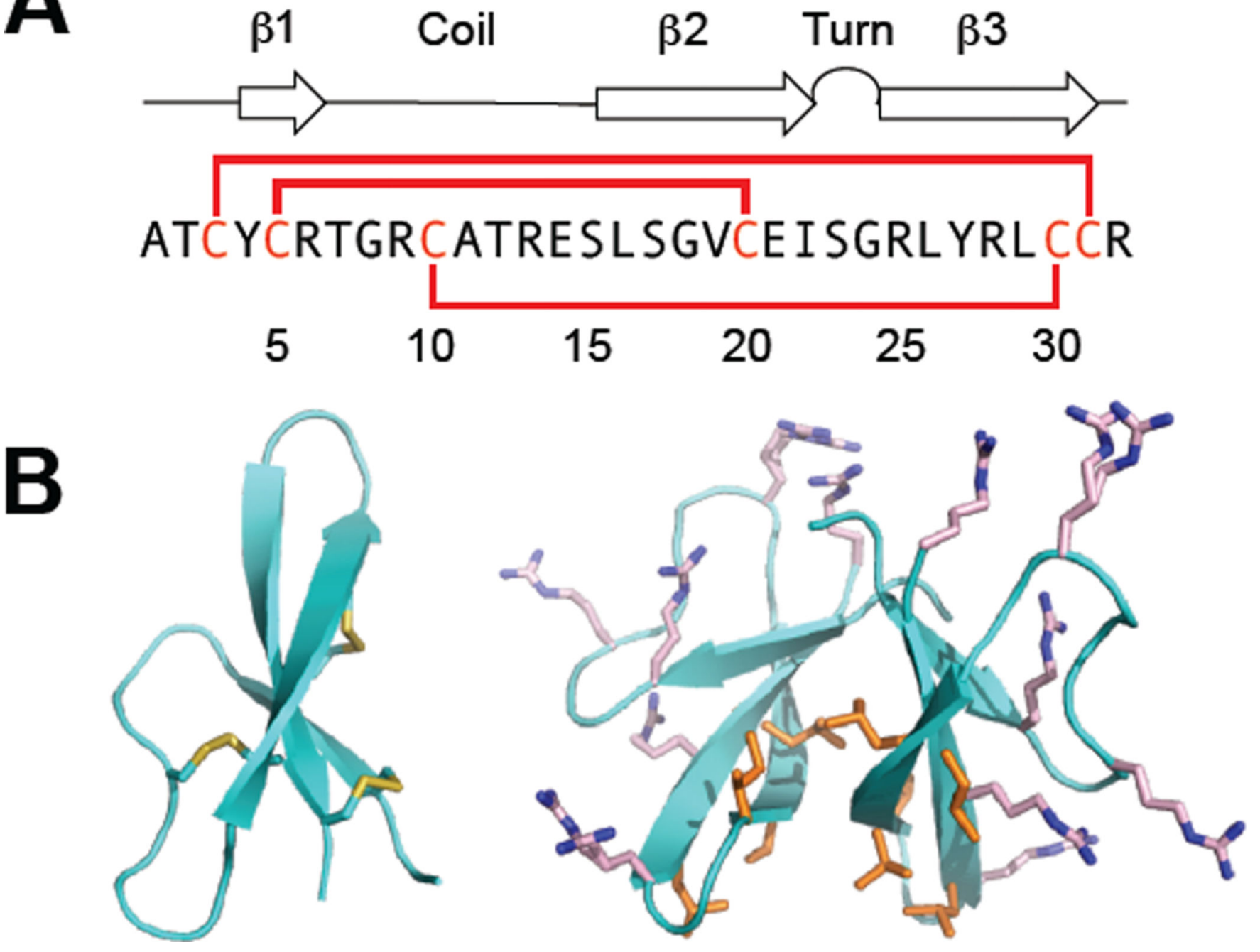

Figure 4.

Overview of HD5. (A) The amino acid sequence of HD5 and a cartoon showing its secondary structure. The solid red lines represent the disulfide linkages. (B) Crystal structures of HD5 monomer (left) and dimer (right) (PDB 1ZMP (Szyk et al., 2006)). The hydrophobic residues of HD5 are distributed at the tetrameric interface, whereas the Arg residues are distributed on the opposite face of the dimer, which is exposed to the surface after tetramerization. The hydrophobic residues are shown in orange and the Arg residues are shown in pink. A color version of the figure is available online. 

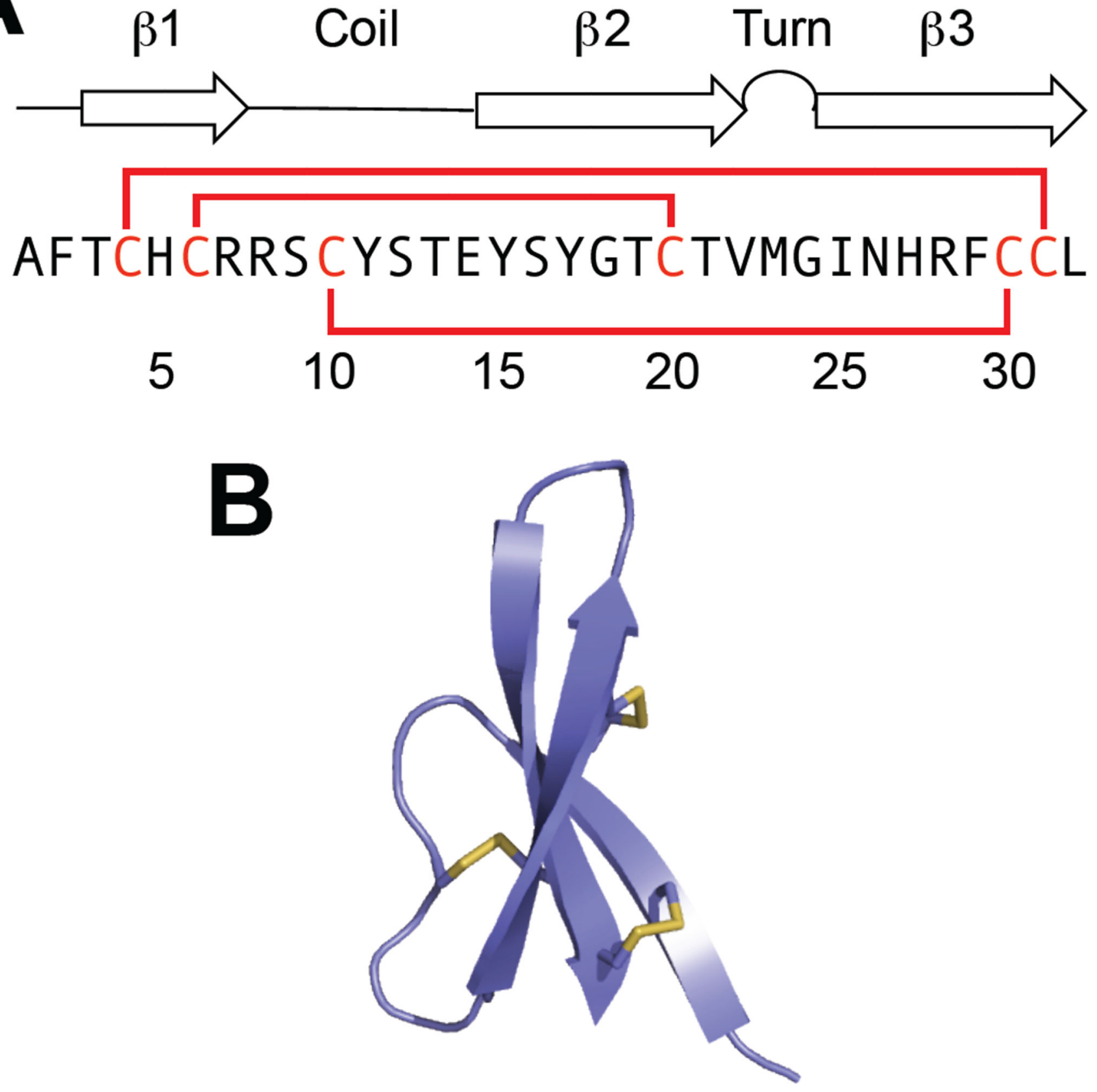

Figure 5.

Overview of HD6. (A) The amino acid sequence of HD6 and a cartoon showing its secondary structure. The solid red lines represent the disulfide linkages. (B) Crystal structure of HD6 monomer (PDB 1ZMQ (Szyk et al., 2006)) with disulfide bonds shown in yellow. A color version of the figure is available online. 


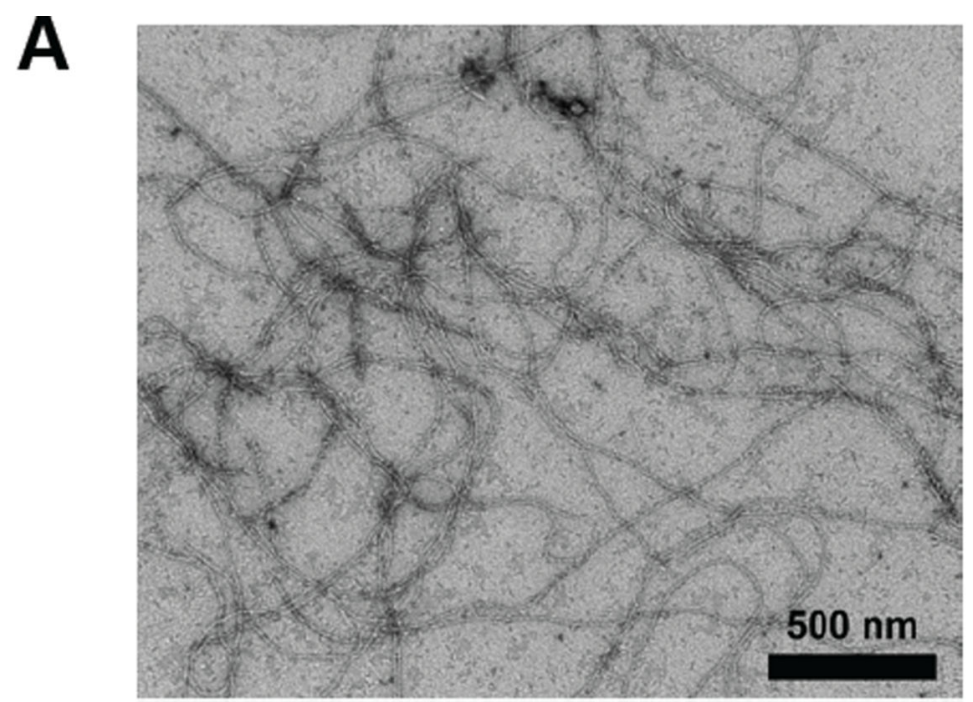

B

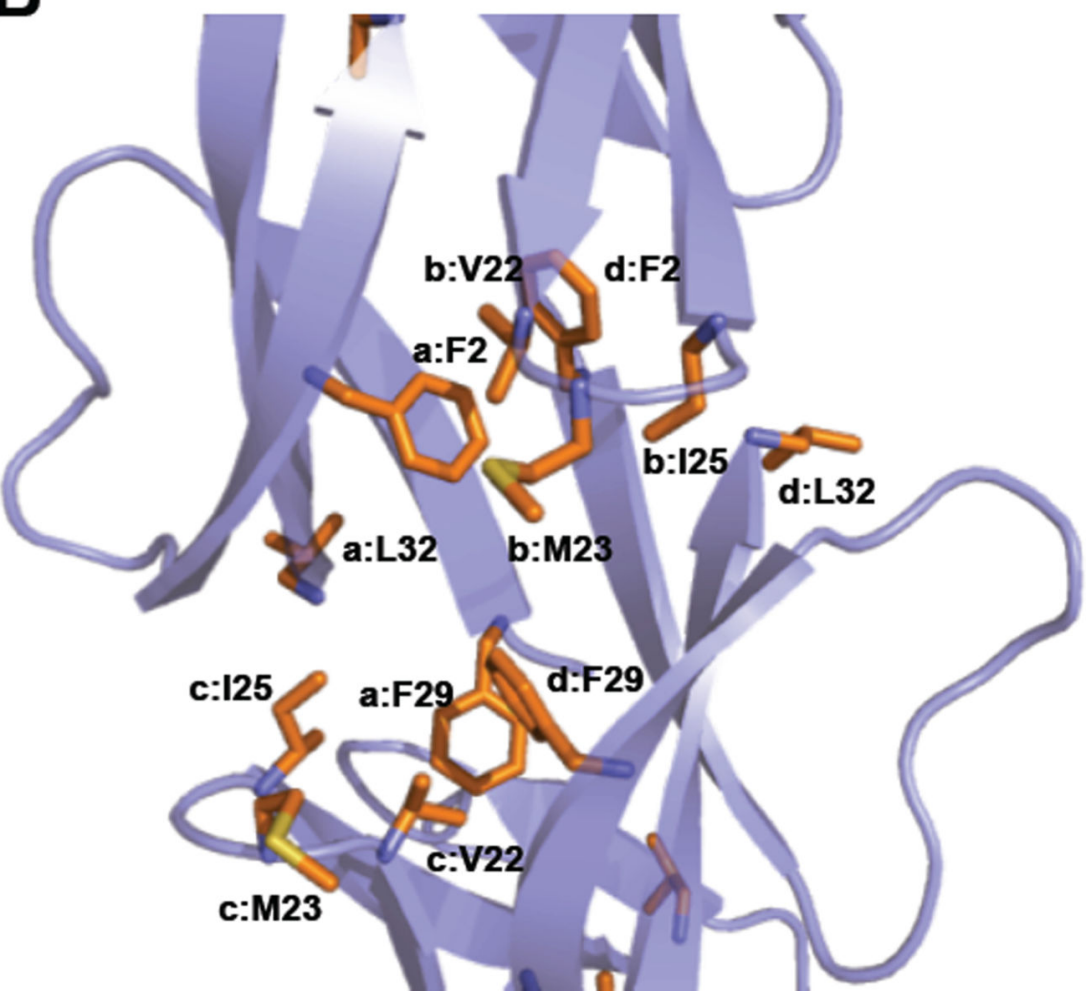

Figure 6.

Self-assembly of HD6. (A) Transmission electron micrograph of $20 \mu \mathrm{M}$ HD6 in $10 \mathrm{mM}$ sodium phosphate, pH 7.4. (B) Crystal structure of HD6 monomers (PDB 1ZMQ (Szyk et al., 2006)) showing the hydrophobic pocket that drives the self-assembly of HD6. Individual HD6 monomers are labeled as a-d. A color version of the figure is available online. 
MUC1

\section{N-glycosylation}

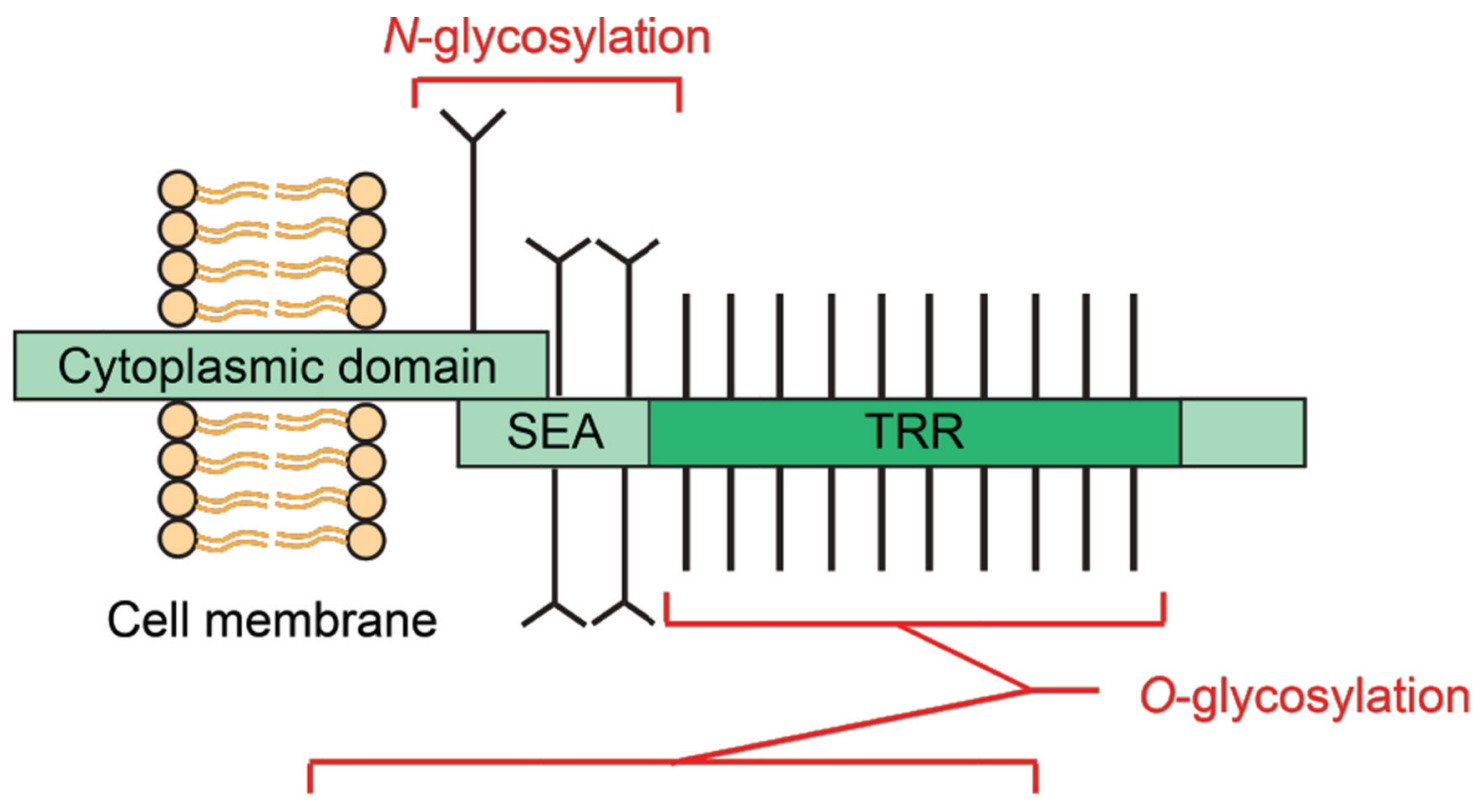

MUC2

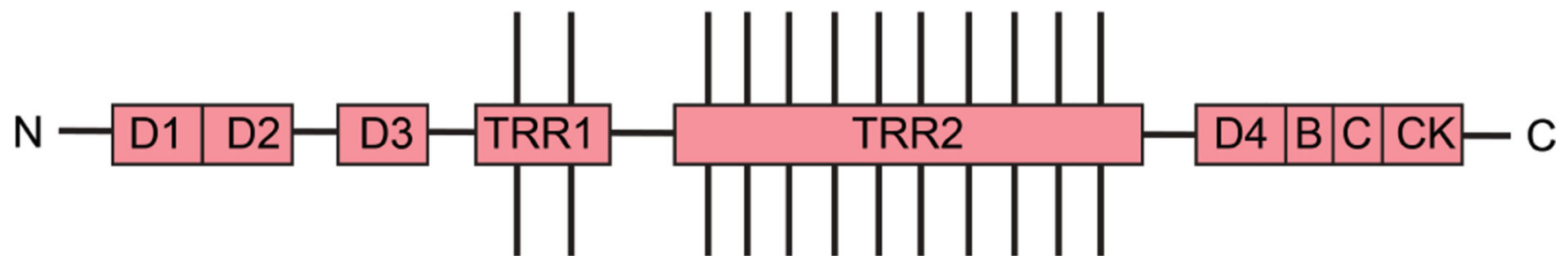

Figure 7.

Structures of mucins. The structure of mucin 1 (MUC1) represents the typical structure of membrane-bound mucins in the GI tract. The extracellular TRR is heavily $O$-glycosylated, and the protein is $N$-glycosylated near the SEA domain. The cytoplasmic domain of MUC1 is involved in intracellular transduction. Mucin 2 (MUC2) is a major component of the secreted mucus barrier in the intestine. The TRRs are heavily $O$-glycosylated and the N-and $\mathrm{C}$-terminal D domains are involved in homo-oligomerization. A color version of the figure is available online. 

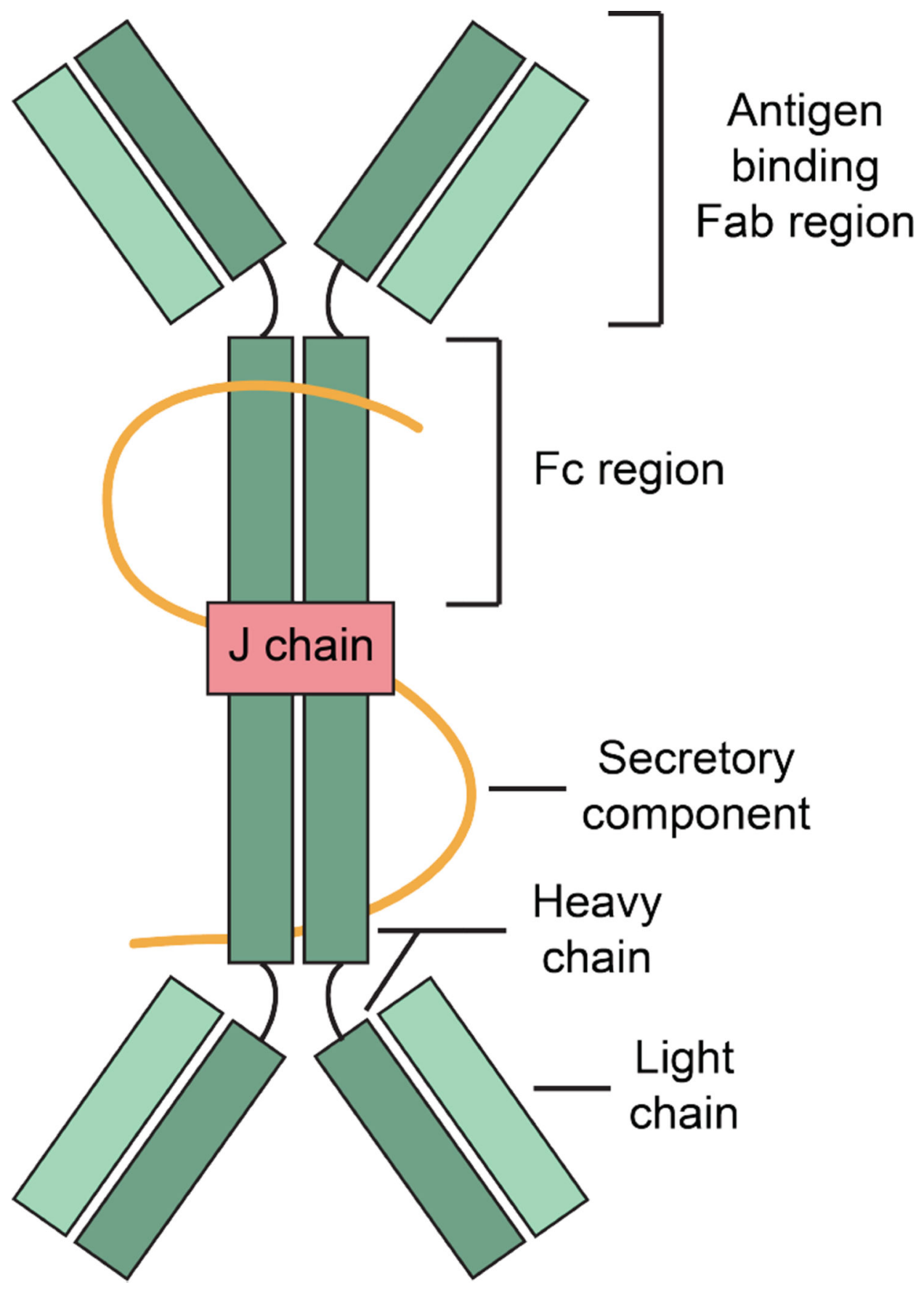

Figure 8.

A cartoon represents the overview structure of $\operatorname{SIgA}$. SIgA are dimeric with two IgA molecules held together by a joining chain (J-chain). Each IgA molecule consists of two heavy chains and two light chains. The secretory component protects the antibody from being degraded by the enzymes of the digestive system. A color version of the figure is available online. 